\title{
Expression Profiling of TGF- $\beta$ Receptor and its Relation with Endometriosis
}

\author{
${ }^{1}$ Soma Ghoshal, ${ }^{2}$ Nisha Rani Agrawal, ${ }^{3}$ Kiran Singh
}

\section{ABSTRACT}

Study objectives: To measure the transforming growth factorbeta (TGF- $\beta$ ) receptor level in endometriotic tissues in patients selected for surgery in our hospital; and thus to assess its genetic basis in the pathophysiology of endometriosis; and to study its possibility as a potent tissue marker.

Design: Observational study (case control study) involving Genetic Laboratory Study.

Setting: Tertiary Care Institute, Gynecology Department.

Population or sample: Total 100 female patients undergoing surgery in our hospital involved; out of them 50 were cases and 50 controls.

Materials and methods: Fifty cases (having endometriosis) and 50 controls (without endometriosis) were taken. During surgery, excised specimen was examined for presence of any endometriotic tissue. The endometrial tissue samples from suspected area were taken and put immediately in RNA-PCR media and sent to Genetics Laboratory where semi-quantitative RT-PCR analysis of TGF-beta was done using primers designed by Primer Blast software (National Center for Biotechnology Information).

Main outcome measures: The mean TGF- $\beta$ receptor level was 0.5886 in cases and the mean TGF- $\beta$ receptor level in controls was 2.076. Both in extrauterine endometriosis and in adenomyosis, TGF- $\beta$ receptor was downregulated equally in $80 \%$ of cases.

Results: Transforming growth factor-beta receptor levels in all types of endometriosis showed a significant down regulation in maximum number of cases.

Conclusion: This downregulation of TGF- $\beta$ receptor level in the endometriotic tissues not only helps in understanding the pathological basis of endometriosis but most importantly, it can be utilized as genetic basis of therapy in endometriosis in near future.

\footnotetext{
${ }^{1}$ Resident, ${ }^{2}$ Consultant, ${ }^{3}$ Assistant Professor

1,2Department of Obstetrics and Gynecology, Institute of Medical Sciences, Banaras Hindu University, Varanasi, Uttar Pradesh, India

${ }^{3}$ Department of Molecular and Human Genetics, Institute of Medical Sciences, Banaras Hindu University, Varanasi, Uttar Pradesh, India

Corresponding Author: Soma Ghoshal, Resident, Department of Obstetrics and Gynecology, Institute of Medical Sciences Banaras Hindu University, Varanasi, Uttar Pradesh, India, Phone: 07301663373, e-mail: soma_ghoshal@yahoo.com
}

Keywords: Downregulation, Endometriosis, PCR analysis, Transforming growth factor.

How to cite this article: Ghoshal S, Agrawal NR, Singh K. Expression Profiling of TGF- $\beta$ Receptor and its Relation with Endometriosis. Int J Infertil Fetal Med 2015;6(3):112-117.

\section{Source of support: Nil}

Conflict of interest: None

Consent: Taken from all the 100 patients involved.

Date of received: $28-09-15$

Date of acceptance: $15-12-15$

Date of publication: December 2015

\section{INTRODUCTION}

Endometriosis is an estrogen-dependent chronic gynecological disorder, usually associated with pelvic pain and infertility. ${ }^{1}$ Very little is known about the underlying mechanisms of endometriosis which affects around $10 \%$ of reproductive age group women. ${ }^{2,3}$

As early diagnosis of endometriosis and initiation of its treatment can improve the gynecological future of patient and can also prevent progression, the study of role of genetics and immunological studies is complementary to this approach.

To date many cytokines suspected to be involved in endometriosis have been analyzed. In this review, we concentrate on transforming growth factor-beta (TGF- $\beta$ ), because we suspect that they may play a major role in the biological processes leading to establishment and maintenance of endometriosis.

Transforming growth factor-beta (TGF- $\beta$ ) are implicated in the gene expression, cell motility, proliferation, apoptosis, differentiation, immune responses and tumorigenesis. ${ }^{4}$ Transforming growth factor-beta is an extracellular protein predominantly produced by a subset of T-cells and is ubiquitously expressed by all cells. In mammals, three isoforms of TGF- $\beta$ are currently identified. Transforming growth factor-beta was the first to be discovered and most studied. Unless specified, TGF- $\beta$ in the literature refers to the isoform TGF- $\beta-1,{ }^{1,5}$

Our review study examines the role of TGF- $\beta$ in the human endometrium and in the pathophysiology of endometriosis; and with the help of RNA-PCR study, we have precisely measured the genetic profiling and downregulation of TGF- $\beta$ receptor levels in endometriosis. 


\section{MATERIALS AND METHODS}

Our study was conducted in the department of obstetrics and gynecology, Institute of Medical Sciences, Banaras Hindu University, Varanasi, Uttar Pradesh, India. Fifty cases and 50 controls were selected. So, genetic study was done in total 100 women undergoing surgery in our hospital.

Selection of cases: Samples were taken from those areas which were peroperatively diagnosed as endometriosis or adenomyosis according to the naked eye appearance of the uterus, ovary and/or pouch of Douglas, in those patients who were admitted and operated in the department of obstetrics and gynecology, Institute of Medical Sciences. Only those tissue samples excised were included as cases for our study which were confirmed to be endometriotic tissue on histopathological diagnosis.

Selection of controls: Controls included fertile female of comparable age group with eumenorrhea, to be operated for reason other than endometriosis. Women with any kind of inflammatory disease, pelvic inflammatory disease, urinary tract infection, functional cyst, irritable bowel syndrome, genital tuberculosis, etc. were excluded from being selected as controls.

\section{Inclusion Criteria of Cases}

- Women in reproductive age group

- With symptoms of endometriosis. At least one clinical symptom must be present (e.g. dysmenorrhea, pelvic pain, infertility, etc.)

- Who were peroperatively diagnosed as endometriosis according to the naked eye appearance of the uterus, ovary and/or pouch of Douglas.

- From whom specimen/sample of endometriotic tissue could be taken during the open or laparoscopic abdominal surgeries.

- Whose specimen/tissue sample showed endometriosis on histopathological examination.

\section{Exclusion Criteria of Cases}

Women with inflammatory bowel disease, pelvic inflammatory disease, urinary tract infection, functional cyst, irritable bowel syndrome, genital tuberculosis.

\section{MATERIALS AND METHODS}

Preoperatively, in all our patients, indication of surgery was properly confirmed.

All routine check-ups including a complete blood count, ultrasonography, renal function test (RFT), electrocardiogram (ECG), chest X-ray and blood sugar was done for preanesthetic check-up.
On the basis of detailed history and examination, and ultrasound findings, patients were asked to either undergo laparoscopy or open abdominal hysterectomy.

Excised specimen was instantly examined grossly for presence of any endometriotic tissue.

\section{Diagnostic Features Included}

- Endometriotic vesicles on uterine surfaces

- Patches of brown, white, red, yellow-brown and/ or clear implants. Quite often these implants had a deeper component below the surface and those could only be felt by touch.

- 'Nodule' appearance typical of endometriosis, and

- Chocolate cysts.

The endometrial tissue samples from suspected area were taken and put immediately in RNA-PCR media and sent to Genetics Laboratory. Along with this sample was also sent for histopathological confirmation.

In our study, Quantitative RT-PCR, using an external synthetic ribonucleic acid (RNA) standard (oligonucleotide peptide) had been used to measure the TGF- $\beta$ receptors level.

\section{Steps involved in this RT-PCR study}

- Extraction and purification of RNA

Tissue sample is cut and collected in microcentrifuge tube $+300 \mu \mathrm{l}$ trizole (mixed) $\downarrow$ Homogenize it with glass rod

Incubate at room temperature for 15 minutes Add $1 / 4$ th volume of chloroform $\downarrow$

Centrifuge at $12000 \mathrm{rpm}$ for 15 minutes Collect supernatant in tube $\downarrow$

Add equal volume of isopropranol.

Keep for 16 minutes at room temperature $\downarrow$

Centrifuge at $12000 \mathrm{rpm}$ for 10 minutes at $4^{\circ} \mathrm{C}$

Discard supernatant collect pellet $\downarrow$

Add 70\% alcohol then centrifuge at $7000 \mathrm{rpm}$ for $5 \mathrm{~min}$ utes at $4^{\circ} \mathrm{C}$ $\downarrow$

Air dry pellet

Add 20 micro liter of DEPC water and store at $-80^{\circ} \mathrm{C}$

DNAse treatment of whole RNA extracted 
- Complementory DNA (c-DNA) prepration

$$
\downarrow
$$

Prepare $2 X$ reverse transcription master mix

$$
\downarrow
$$

Add RNA to reverse transcription reaction

$$
\downarrow
$$

Perform reverse transcription in thermal cycle

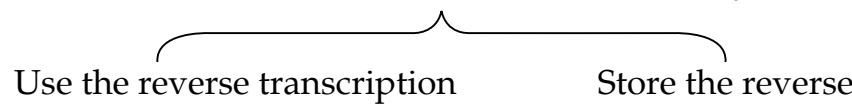

reaction

(c-DNA) directly for quantitative or other

Store the reverse

PCR application

transcription

reaction

(c-DNA) at $2-6^{\circ} \mathrm{C}$

- Performing semi-quantitative RT-PCR for c-DNA sample that are prepared by above mentioned steps.

Total RNA was isolated from endometriotic tissue samples using TRIzol reagent followed by DNAse I treatment. c-DNA was synthesized and semi-quantitative RT-PCR analysis of TGF- $\beta$ was done using primers designed by Primer Blast software (National Center for biotechnology Information). Expression level of all transcripts was quantified after normalization of samples using GAPDH gene.

Complementory DNA of 50 samples were mixed with PCR reaction mixture of volume $12 \mu \mathrm{l}$ each. Each reaction was performed in $15 \mu \mathrm{l}$, where $100 \mathrm{ng}$ of DNA template was added to $1 \mu \mathrm{l}$ of each primer, $160 \mathrm{mM}$ dNTP, $1 \times$ PCR buffer, and $1 \mathrm{U}$ Taq, 35 cycles of incubation were performed using the BioRad PCR System. Each cycle consisted of 30 seconds at $94^{\circ} \mathrm{C}, 55$ seconds at $62^{\circ} \mathrm{C}$, and 55 seconds at $72^{\circ} \mathrm{C}$. The first cycle was preceded by a 5 minutes denaturation step and a single step of extension at $72{ }^{\circ} \mathrm{C}$ for 10 minutes following the last cycle. This overall solution was prepared and put in PCR tube for 3 hours. Expression level of all transcripts was quantified after normalization of samples using glyceraldehyde 3-phosphate dehydrogenase GAPDH gene.

There were 50 cases in total whose tissue samples were grossly as well as histopathologically found to be positive for endometriosis. Similarly, there were 50 controls whose tissue sample was grossly as well as histopathologically found to be negative for endometriosis.

\section{OBSERVATIONS/RESULTS}

Table 1 is depicting the TGF- $\beta$ receptor levels in various types of endometriosis; the last 10 cases are of adenomyosis, and case no. 18 and 19 are of bowel endometriosis. All others are uterine and/or ovarian endometriosis.

Among the 50 cases, 10 cases were of adenomyosis (the last 10 cases as shown in Table 1). All others were uterine and/or ovarian endometriosis.
Among the total 50 cases, nine cases showed no change in their receptor level, whereas the rest of 41 cases showed a decrease in the TGF- $\beta$ receptor level.

\begin{tabular}{|c|c|c|}
\hline Cases sl. no. & $\begin{array}{l}\text { TGF- } \beta \text { receptor } \\
\text { level }\end{array}$ & $\begin{array}{l}\text { Change from mean } \\
\text { value of } T G F-\beta \text { receptor } \\
\text { level }\end{array}$ \\
\hline 1 & 0.75 & $\downarrow$ \\
\hline 2 & 1.09 & $\downarrow$ \\
\hline 3 & 0.66 & $\downarrow$ \\
\hline 4 & 1.62 & No change \\
\hline 5 & 1.72 & No change \\
\hline 6 & 0.75 & $\downarrow$ \\
\hline 7 & 0.62 & $\downarrow$ \\
\hline 8 & 1.86 & No change \\
\hline 9 & 0.44 & $\downarrow$ \\
\hline 10 & 1.48 & No change \\
\hline 11 & 0.4 & $\downarrow$ \\
\hline 12 & 0.29 & $\downarrow$ \\
\hline 13 & 0.25 & $\downarrow$ \\
\hline 14 & 0.18 & $\downarrow$ \\
\hline 15 & 0.16 & $\downarrow$ \\
\hline 16 & 0.48 & $\downarrow$ \\
\hline 17 & 0.26 & $\downarrow$ \\
\hline 18 & 0.28 & $\downarrow$ \\
\hline 19 & 0.23 & $\downarrow$ \\
\hline 20 & 0.29 & $\downarrow$ \\
\hline $21(a)$ & 0.25 & $\downarrow$ \\
\hline 22(a) & 0.14 & $\downarrow$ \\
\hline $23(a)$ & 1.18 & No change \\
\hline $24(a)$ & 0.26 & $\downarrow$ \\
\hline $25(a)$ & 0.18 & $\downarrow$ \\
\hline 26 & 0.25 & $\downarrow$ \\
\hline 27 & 0.18 & $\downarrow$ \\
\hline 28 & 0.16 & $\downarrow$ \\
\hline 29 & 0.48 & $\downarrow$ \\
\hline 30 & 0.26 & $\downarrow$ \\
\hline 31 & 0.66 & $\downarrow$ \\
\hline 32 & 0.62 & $\downarrow$ \\
\hline 33 & 1.72 & No change \\
\hline 34 & 0.29 & $\downarrow$ \\
\hline 35 & 0.25 & $\downarrow$ \\
\hline 36 & 0.18 & $\downarrow$ \\
\hline 37 & 0.16 & $\downarrow$ \\
\hline 38 & 0.48 & $\downarrow$ \\
\hline 39 & 1.72 & No change \\
\hline 40 & 0.75 & $\downarrow$ \\
\hline 41 & 0.62 & $\downarrow$ \\
\hline 42 & 1.86 & No change \\
\hline 43 & 0.44 & $\downarrow$ \\
\hline 44 & 0.26 & $\downarrow$ \\
\hline 45 & 0.18 & $\downarrow$ \\
\hline 46 & 0.23 & $\downarrow$ \\
\hline 47 & 0.29 & $\downarrow$ \\
\hline 48 & 0.25 & $\downarrow$ \\
\hline 49 & 0.14 & $\downarrow$ \\
\hline 50 & 1.18 & No change \\
\hline
\end{tabular}
Among the cases of adenomyosis, eight of the cases

Table 1: TGF- $\beta$ receptor levels in cases 
showed a decrease in their receptor level; the rest two cases showed no change. The mean TGF- $\beta$ receptor level was 0.5886 in cases.

As clearly visible from Table 2, all the controls had their TGF- $\beta$ receptor levels within normal limit. The mean TGF- $\beta$ receptor level in controls was 2.076 .

Table 2: TGF- $\beta$ receptor levels in controls

\begin{tabular}{|c|c|c|}
\hline Controls & TGF- $\beta$ receptor level & Change from mean value \\
\hline 1 & 2.7 & No change \\
\hline 2 & 2.9 & No change \\
\hline 3 & 2.07 & No change \\
\hline 4 & 1.59 & No change \\
\hline 5 & 2.12 & No change \\
\hline 6 & 1.47 & No change \\
\hline 7 & 1.70 & No change \\
\hline 8 & 2.26 & No change \\
\hline 9 & 2.39 & No change \\
\hline 10 & 1.27 & No change \\
\hline 11 & 2.23 & No change \\
\hline 12 & 1.35 & No change \\
\hline 13 & 3.34 & No change \\
\hline 14 & 2.26 & No change \\
\hline 15 & 2.23 & No change \\
\hline 16 & 2.21 & No change \\
\hline 17 & 2.23 & No change \\
\hline 18 & 2.09 & No change \\
\hline 19 & 2.31 & No change \\
\hline 20 & 1.98 & No change \\
\hline 21 & 1.87 & No change \\
\hline 22 & 1.76 & No change \\
\hline 23 & 1.89 & No change \\
\hline 24 & 2.67 & No change \\
\hline 25 & 3.09 & No change \\
\hline 26 & 2.39 & No change \\
\hline 27 & 1.27 & No change \\
\hline 28 & 2.23 & No change \\
\hline 29 & 2.31 & No change \\
\hline 30 & 1.98 & No change \\
\hline 31 & 1.87 & No change \\
\hline 32 & 1.59 & No change \\
\hline 33 & 2.12 & No change \\
\hline 34 & 1.47 & No change \\
\hline 35 & 2.39 & No change \\
\hline 36 & 1.27 & No change \\
\hline 37 & 2.23 & No change \\
\hline 38 & 1.35 & No change \\
\hline 39 & 1.26 & No change \\
\hline 40 & 1.32 & No change \\
\hline 41 & 1.98 & No change \\
\hline 42 & 1.87 & No change \\
\hline 43 & 1.59 & No change \\
\hline 44 & 2.67 & No change \\
\hline 45 & 3.09 & No change \\
\hline 46 & 2.39 & No change \\
\hline 47 & 2.23 & No change \\
\hline 48 & 1.35 & No change \\
\hline 49 & 3.34 & No change \\
\hline 50 & 2.26 & No change \\
\hline
\end{tabular}

Since none of the controls showed any downregulation in their TGF- $\beta$ receptor level, so odds ratio (OR) cannot be calculated (because one of the cells has the value zero). So, our study proves that there is a clear-cut down regulation of TGF- $\beta$ receptor level (Table 3 ) in cases of endometriosis.

Table 4 shows that both in extrauterine endometriosis and in adenomyosis, TGF- $\beta$ receptor was downregulated in almost equally in $80 \%$ of cases.

Since our study needed tissue sampling from pathological sites, so those infertile patients from whom tissue could not be taken, e.g. those with only few endometriotic implants in their peritoneum/cul de sac could not be included in our study.

\section{DISCUSSION}

Endometriosis is a puzzling disease with little known about its true prevalence, its risk factors and its potent diagnostic markers. The overall prevalence is unknown, primarily because surgery is the only reliable method for diagnosis and generally is not performed on women without symptoms or physical findings that strongly suggest the possibility; estimates vary by diagnosis.

As such endometriosis diagnosis requires the identification of two entities, i.e. presence of endometrial glands and stroma in ectopic places. ${ }^{1,5}$

Endometriosis is a multifactorial disease and so genetic studies as such are difficult to approach due to the uncertainty of a polygenic trait. ${ }^{5,6}$ Genetic identification is essential for early diagnosis and genetic therapy of the genetically associated diseases.

Endometrial cells may synthesize cytokines and growth factors, which may modulate some of the molecular mechanisms of endometrial proliferation and differentiation. To date many cytokines ${ }^{2}$ most importantly

Table 3: Total no. of cases and controls with down regulation of TGF- $\beta$ receptor level

\begin{tabular}{lll}
\hline Patients & $\begin{array}{l}\text { No. of patients with } \\
\text { Downregulation }\end{array}$ & $\begin{array}{l}\text { No. of patients with } \\
\text { Normal level }\end{array}$ \\
\hline $\begin{array}{l}\text { Cases (with } \\
\text { Endometriosis) }\end{array}$ & $41(82 \%)$ & $9(18 \%)$ \\
$\begin{array}{l}\text { Controls (without } \\
\text { Endometriosis) }\end{array}$ & $0(0 \%)$ & $50(100 \%)$ \\
\hline
\end{tabular}

Table 4: Comparative study of endometriosis and adenomyosis regarding downregulation of TGF- $\beta$ receptor level

\begin{tabular}{llll}
\hline & $\begin{array}{l}\text { No. of cases } \\
\text { with down- } \\
\text { regulation }\end{array}$ & $\begin{array}{l}\text { No. of cases } \\
\text { with normal } \\
\text { level }\end{array}$ & $\begin{array}{l}\text { Total no. of } \\
\text { cases }(n=50)\end{array}$ \\
\hline $\begin{array}{l}\text { Extra-uterine } \\
\text { endometriosis }\end{array}$ & $33(82.5 \%)$ & $7(17.5 \%)$ & 40 \\
Adenomyosis & $8(80 \%)$ & $2(20 \%)$ & 10 \\
\hline
\end{tabular}


CA-125, IL-1,6, macrophage chemotactic protein-1 (MCP-1), leptin and macrophage migration inhibitory factor (MIF) ${ }^{7}$ have been discussed to be involved; but none of these have been found reliable or validated enough to be qualified as a potential molecular marker for endometriosis.

\section{Role of TGF- $\beta$ as Potent Markers for Diagnosis of Endometriosis}

Transforming growth factor-beta are abundantly and differentially expressed in the endometrium ${ }^{1,8}$ and are secreted by endometrial cells and macrophages into the uterine fluid. Secretion of TGF- $\beta$ into peritoneal fluid of women suffering from endometriosis suggests that they may be crucial in establishment and/or maintenance of endometriosis. TGF- $\beta$ mRNA is present in both stromal and glandular epithelial cells cultured from the endometrium. ${ }^{8}$ Since it has been shown that TGF- $\beta$ inhibits the growth of glandular epithelial cells, it can be hypothesized that the mechanism of growth inhibition by TGF- $\beta$ may be altered or perturbed in endometrial hyperplasia and carcinoma. ${ }^{8}$ Therefore, we studied the mRNA expression of TGF- $\beta$ isoforms in tissue samples from the endometrium by RT-PCR analysis.

Stage-specific expression of all TGF- $\beta$ and their highaffinity receptors in the human endometrium indicate that they are under negative hormonal control although conclusive evidence is still lacking. ${ }^{1}$ It has been suggested that TGF- $\beta$ participate in the initiation of menstruation via vasoconstriction, in menstrual tissue repair and in endometriosis. Consequently, it has been proposed that TGF- $\beta$ s might be potent factors involved in pathogenesis of endometriosis. ${ }^{1}$

Transforming growth factor beta is a multifunctional cytokine that belongs to a group of cytokines that is collectively called 'The TGF- $\beta$ superfamily', ${ }^{5,9}$ members of which regulate epithelial cell growth, differentiation, motility, organization, apoptosis ${ }^{4}$ and tumorogenesis. ${ }^{5}$

Transforming growth factor-beta is an extracellular protein predominantly produced by a subset of T-cells and is ubiquitously expressed by all cells. It is both a stimulator and inhibitor of cellular replication and controls the production of many extracellular matrices. Transforming growth factor-beta stimulates cells of mesenchymal origin and profoundly inhibits epithelial proliferation (anti-mitogenic). ${ }^{4}$

\section{Transforming Growth Factor-beta Receptors and Binding Proteins}

Virtually all cells in the human body have TGF- $\beta$ receptors. Nine membrane protein receptors ${ }^{10-12}$ have currently been identified. There are several classes of cell-surface receptors that bind different TGF- $\beta$ with different affinities. The most widely distributed of these are TGF- $\beta$ receptors I and II with molecular weights of 53 and $70 \mathrm{kDa}$, respectively. ${ }^{1,10-12}$

Loss of the type I and/or type II receptor correlates with the loss of cellular responsiveness to TGF- $\beta$. There are cell-type specific differences in receptor sub-types. Unlike the epidermal growth factor (EGF), platelet derived growth factor (PDGF) and fibroblast growth factor (FGF) receptors, the TGF- $\beta$ family receptors all have intrinsic serine threonine kinase activity ${ }^{10,12,13}$ and, therefore, induce distinct cascades of signal transduction. On binding with its surface receptors TGF- $\beta$ proteins transmit their signals to an intracellular protein called Smad. ${ }^{10-13}$ The generation of this signal and its interaction is complex resulting in the Smad protein being transported rapidly into the nucleus and engaging in complex mechanisms of gene regulation in association with chromatin and transcription factors. Smad proteins are subsequently degraded in the cytoplasm.

Previous studies and literatures have indicated that subjects with endometriosis exhibit higher levels of TGF- $\beta 1$ in peritoneal fluid. ${ }^{1,14}$ However, regarding the genetic profiling of TGF- $\beta$ receptor in endometriosis, only few conflicting reports have been published to date. In our review study, we have precisely measured the genetic profiling (Tables 1 and 2) and downregulation of TGF- $\beta$ receptor levels in endometriosis (Tables 3 and 4 ) and also have discussed the role of TGF- $\beta$ in the human endometrium and in the pathophysiology of endometriosis.

High TGF- $\beta$ levels around menstruation might increase production of endothelin-1, a potent vasoconstrictor involved in endometrial bleeding and cessation thereof, by endometrial epithelial cells ${ }^{1,14}$ suggesting that TGF- $\beta$ may indirectly induce menses via vasoconstriction.

\section{Suppression of the Immune System}

That TGF- $\beta 1$ represses the immune system was demonstrated in knockout mice that died of multiorgan inflammation. ${ }^{15,16}$ Target cells included lymphocytes, especially regulatory $\mathrm{T}$ cells, cytolytic $\mathrm{T}$ cells, natural killer (NK) cells and macrophages. Additional studies have demonstrated that TGF- $\beta 1$ inhibits IFN- $\gamma$ and IL-10 secretion by uterine NK (uNK) cells in the human endometrium, and that blocking TGF- $\beta 1$ in human endometrial cells increases secretion of IFN- $\gamma$ by $\mathrm{uNK}^{9}$ possibly by increased production of Toll-like receptor agonist. ${ }^{1,9}$

In the study conducted by D'Hooghe et al (2002), ${ }^{7}$ a 2 -fold increase in peritoneal fluid concentration of TGF- $\beta$ was found but no association of higher TGF- $\beta 1$ levels was 
seen with higher stages; whereas in another study, by Pizzo et al (2002) ${ }^{17}$ higher TGF- $\beta 1$ levels were associated with higher stage-specificity in endometriosis. Previous studies and literatures have indicated that subjects with endometriosis exhibit higher levels of TGF- $\beta 1$ in peritoneal fluid, ${ }^{1,2,14,15}$ However, it is important to stress that in these studies, different enzyme-linked immunosorbent assay (ELISA) protocols were used and, with the exception of one study. Oosterlynck et al 1994, ${ }^{14}$ the authors did not indicate whether or not the total or bioactive levels of TGF- $\beta 1$ were analyzed. ${ }^{1}$ Consequently, we suggest that further studies with higher subject numbers and standardized ELISA protocols are needed before a final conclusion can be reached regarding specificity of the TGF- $\beta$ as potent diagnostic markers for endometriosis. Future studies should also take into account that impaired TGF- $\beta 1$ levels have been demonstrated also in some cancers, autoimmune diseases, artherosclerosis, osteoporosis and fibrosis and that few drugs including aspirin, tamoxifen also modulate plasma TGF- $\beta 1$ levels. ${ }^{18}$

\section{CONCLUSION}

Women with downregulation of TGF- $\beta$ receptor level in the endometriotic tissues might be at increased risk for developing endometriosis. Further studies are necessary to determine whether the receptor levels are predictive of an ensuing lesion of endometriosis and whether TGF- $\beta$ as a marker might be used to determine disease probability or prognosis.

The downregulation of TGF- $\beta$ receptor level in the endometriotic tissues not only helps in understanding the pathological basis of endometriosis but most importantly, this downregulation of receptor level can be utilized as genetic basis of therapy in endometriosis in near future.

\section{ACKNOWLEDGMENT}

I take this opportunity to express my profound gratitude and deep regards to my revered teacher and supervisor Professor Nisha Rani Agrawal, department of obstetrics and gynecology, Institute of Medical Sciences, Banaras Hindu University, Varanasi for her exemplary guidance, expert supervision, and continuous motivation rendered to me at every phase of my research.

\section{REFERENCES}

1. Omwandho COA, Konrad L, Halis G, Oehmke F, Hans-Rudolf T. Role of TGF-bs in normal human endometrium and endometriosis. Hum Reprod 2009;00(0):1-9.

2. May KE, Conduit-Hulbert SA, Villar J, Kirtley S, Kennedy SH, Becker CM. Peripheral biomarkers of endometriosis: a systematic review. Hum Reprod Update 2010;00(0):1-24.
3. Montgomery GW, Nyholt DR, Zhao ZZ, Treloar SA, Jodie N, Missmer SPA, Kennedy SH, Zondervan KT. The search for genes contributing to endometriosis risk. Hum Reprod Update 2008;14(5):447-457.

4. Bursch W, Oberhammer F, Jirtle RL, Askaril M, Sedivy R, Grasl-Krauppl B, Purchio AF, Schulte-Hermann R. Transforming growth factor-pl as a signal for induction of cell death by apoptosis. Br J Cancer 1993;67:531-536.

5. Yao-Yuan H, Chi-Chen C, Fuu-Jen T, Ching-Tien P, Lian-Shun Y, Cheng-Chieh L. Polymorphism for Transforming Growth Factor Beta 1-509 (TGF-B1-509): Association with Endometriosis. Biochem Genet 2005;43(5/6):203-210.

6. Adachi S, Tajima A, Quan J, Haino K, Yoshihara K, Masuzaki H, Katabuchi H, Ikuma K, Suginami H, Nishida N, et al. Meta-analysis of genome-wide association scans for genetic susceptibility to endometriosis in Japanese population. J Hum Genet 2010;55:816-821.

7. D'Hooghe TM, Debrock S. Endometriosis, retrograde menstruation and peritoneal inflammation in women and in baboons. Hum Reprod Update 2002;8(1):84-88.

8. Gold LI, Saxena B, Mittal KR, Marmor M, Goswami S, Nactigal L, Korc M, Rita I. Demopoulos. Increased expression of transforming growth factor $\beta$ isoforms and basic fibroblast growth factor in complex hyperplasia and adenocarcinoma of the endometrium: evidence for paracrine and autocrine action. Cancer Res 1994;54:2347-2358.

9. Jones RL, Stoikos C, Findlay JK, Salamonsen LA. TGF- $\beta$ superfamily expression and actions in the endometrium and placenta. J Reprod 2006;132:217-232.

10. Attisano L, Wrana JL. Signal transduction by the TGF- $\beta$ superfamily. Sci J 2002;296(5573):1646-1647.

11. Carl-Henrik H, Miyazono K, Dijke PT. TGF-b signalling from cell membrane to nucleus through SMAD proteins. Nature J 1997;390:465-471.

12. Ya-guang L, Tekmal RR, Binkley PA, Nair HB, Schenken RS, Kirma NB. Induction of endometrial epithelial cell invasion and c-FMS expression by transforming growth factor beta. Molecular Hum Reprod 2009;15(10):665-673.

13. Sun-Wei G. Epigenetics of endometriosis. Molecular Hum Reprod 2009;15(10):587-607.

14. Oosterlynck DJ, Meuleman C, Waer M, Koninckx PR. Transforming Growth Factor-[beta] activity is increased in peritoneal fluid from women with Endometriosis. Obstet Gynecol 1994;83(2):287-292.

15. Yoshimura A, Wakabayashi Y, Mori T. Cellular and molecular basis for the regulation of inflammation by TGF- $\beta$. J. Biochem 2010;147(6):781-792.

16. Gorelik L, Flavell RA. Abrogation of TGF- $\beta$ signaling in T cells leads to spontaneous T cell differentiation and Autoimmune Disease. Immunity 2000;12:171-181.

17. Pizzo A, Salmeri FM, Ardita FV, Sofo V, Tripepi M, Marsico S. Behavior of cytokine levels in serum and peritoneal fluid of women with endometriosis. Gynecol Obstet Invest 2002;54(2): 82-87.

18. Grainger DJ, Metcalfe JC, Grace AA, Mosedale DE. Transforming growth factor $\beta$ dynamically regulates vascular smooth muscle differentiation in vivo. J Cell Sci 1999;111: 2977-2988. 